\title{
Lamellorthoceratid cephalopods in the cold waters of southwestern Gondwana: Evidences from the Lower Devonian of Argentina
}

\author{
Marcela Cichowolski and Juan José Rustán \\ Acta Palaeontologica Polonica 65 (2), 2020: 305-312 doi:https://doi.org/10.4202/app.00699.2019
}

Based on three specimens assigned to Arthrophyllum sp., the family Lamellorthoceratidae is reported from the Lower Devonian Talacasto Formation in the Precordillera Basin, central western Argentina. These Devonian cephalopods have been known only from low to mid palaeolatitudes and its presence in the cold water settings of southwestern Gondwana is notable. A nektonic mode of life, not strictly demersal but eventually pelagic, with a horizontal orientation of the conch is proposed for adults lamellorthoceratids, whereas a planktonic habit is suggested for juvenile individuals. These features would had allow their arrival to this southern basin, explaining their unusual presence in the Malvinokaffric Realm, and reinforcing the need of re-evaluate the distribution pattern of several groups of cephalopods.

Key words: Cephalopoda, Lamellorthoceratidae, Arthrophyllum, Palaeozoic, Talacasto Formation, Malvinokaffric Realm, Precordillera Basin, Argentina.

Marcela Cichowolski [mcicho@gl.fcen.uba.ar], Instituto de Estudios Andinos

"Don Pablo Groeber" (IDEAN), CONICET, and Facultad de Ciencias Exactas

y Naturales, Universidad de Buenos Aires, Ciudad Universitaria, Pab. 2,

C1428EGA, Buenos Aires, Argentina. Juan J. Rustán [juanjorustan@gmail.com], Centro de Investigaciones en Ciencias de la Tierra (CICTERRA), Centro de Investigaciones Paleobiológicas (CIPAL), CONICET, Universidad Nacional de Córdoba, Av. Vélez Sarsfield No 1611, X5016GCA, Córdoba, Argentina and Universidad Nacional de La Rioja, M. de la Fuente s/n, CP 5300, La Rioja, Argentina.

This is an open-access article distributed under the terms of the Creative Commons Attribution License (for details please see creativecommons.org), which permits unrestricted use, distribution, and reproduction in any medium, provided the original author and source are credited. 
For 5 Full text (509.6 kB) 